\title{
Improved PCR Detection of Blackcurrant reversion virus in Ribes and Further Evidence that It Is the Causal Agent of Reversion Disease
}

\author{
A. Teifion Jones and Wendy J. McGavin, Scottish Crop Research Institute, Invergowrie, Dundee DD2 5DA, UK
}

\begin{abstract}
Jones, A. T., and McGavin, W. J. 2002. Improved PCR detection of Blackcurrant reversion virus in Ribes and further evidence that it is the causal agent of reversion disease. Plant Dis. 86:1333-1338.

Within 5 years of mechanically inoculating blackcurrant cultivars with partially purified preparations of particles of Blackcurrant reversion virus (BRV), infected plants developed leaf and flower bud symptoms typical of reversion disease, demonstrating that BRV is the causal agent of this disease. To improve the erratic immunocapture reverse transcriptase-polymerase chain reaction (RT-PCR) detection of BRV in Ribes plants, various stepwise changes were made to the original protocol. Significant improvement in the reliability and sensitivity of BRV detection was made by extracting RNA from trapped BRV particles using Triton-X 100, the design of new primers with higher annealing temperatures, and the use of 'Ready-to-go' RT-PCR beads. These features, combined with other minor changes to the protocol, improved BRV detection in reverted blackcurrant plants from $<50 \%$ to $>90 \%$ but the reliability of BRV detection in red currant was always very much less and was possible only using nested PCR that was developed for this purpose.
\end{abstract}

Additional keywords: red currant

Reversion is the most important disease of blackcurrant crops worldwide (7) and also affects red currant (1) and some wild Ribes spp. (2). Gooseberry is reported to be immune to infection $(1,11)$. The disease occurs in two forms, the common European (E) form and the more severe (R) form $(6,7)$, found in Scandinavia $(3,16)$, Eastern Europe, and countries of the former Soviet Union. Each form of reversion causes a change in leaf form and shape, decreases the hairiness of flower buds, increases flower pigmentation, decreases plant vigor, and causes plants to become sterile and lose productivity quickly (1). The $\mathrm{R}$ form induces more severe symptoms than the $\mathrm{E}$ form and, in addition, produces severely deformed flowers $(1,7)$. Leaf and flower symptoms in red currant are very much less noticeable than those in blackcurrant. In nature, the causal agent of the disease is transmitted between blackcurrant plants by the blackcurrant gall mite, but not through seed (1).

Recently, a virus, named Blackcurrant reversion associated virus, genus Nepovi-

Corresponding author: A. Teifion Jones

E-mail: tjones@scri.sari.ac.uk

Work at SCRI is grant-aided by the Scottish Executive Environment and Rural Affairs Department.

Accepted for publication 16 July 2002.

Publication no. D-2002-1015-02R

(C) 2002 The American Phytopathological Society rus, was isolated from reverted blackcurrant and characterized (12). The occurrence of this virus in plants was so closely associated with each form of the disease that it was believed to be its causal agent $(11,12)$. More recently, plants inoculated with partially purified preparations of particles of this virus developed chlorotic line patterns in blackcurrant leaves and it was suggested that this fulfilled Koch's postulates and that the virus name should be changed to Blackcurrant reversion virus (14). However, in these experiments, the classic reversion disease syndrome in leaf morphology and flower symptoms, which may take more than 2 years to develop in graftinoculated blackcurrant plants (7), was not reported in the inoculated plants (14). Moreover, such line-pattern symptoms have been noted in plants infected with other unrelated viruses $(7,9)$ and in blackcurrant cultivars resistant to reversion disease (8). Therefore, it was considered premature to change the virus name (7). However, we now report the expression of these classic reversion disease symptoms (Fig. 1) in blackcurrant plants infected by mechanical inoculation with partially purified particle preparations of the $R$ form of this virus, thus fulfilling Koch's postulates as far as they can be applied to plant viruses. This evidence demonstrates that this virus is the causal agent of the disease and we support its change of name to Blackcurrant reversion virus (BRV); we use this designation throughout this article.

The initial association of BRV with reversion disease was based on an immuno- capture (IC) reverse transcriptase-polymerase chain reaction (RT-PCR) assay to detect the virus. Using this sensitive assay, the association of this virus with reversion disease was found to be very close, but not complete $(11,12)$. One explanation for the few discrepancies experienced in these studies was the demonstrated erratic distribution of BRV in different branches and nodes of infected plants (11). In view of this factor, careful consideration is needed in collecting samples from bushes to be tested so as to maximize the likelihood of detection. Detection of BRV in red currant is even more erratic than that in blackcurrant, making accurate diagnosis difficult (A. T. Jones and W. J. McGavin, unpublished data).

An alternative, or additional, explanation for the failure to detect BRV in some reverted samples is that the virus occurs in some tissues at concentrations below the detection limit of the assay $(11,12)$. Using 5' fluorescein-labeled oligonucleotide primers and detecting the product after PCR in an automated sequencing apparatus improved detection further. This indicated that the poor detection of weak positive products in agarose gels limits the overall sensitivity of the assay. The increased sensitivity obtained by automated detection is costly, making it unsuitable for use in testing large numbers of samples.

In our hands, the routine use of the ICRT-PCR protocol (12) has varied greatly in its apparent sensitivity and efficiency in detecting BRV in some blackcurrant assays, and much more so in red currant. Therefore, we have sought to improve the reliability of detection by changing several parameters of the original protocol and by nested PCR. We report here the design of new primers, the use of a different RNA extraction protocol, the use of RT-PCR beads (Amersham Pharmacia Biotech) for the improved sensitivity, and hence reliability, of BRV detection by RT-PCR in blackcurrant, and the use of nested PCR to increase the sensitivity further, allowing more reliable detection of BRV in both blackcurrant and red currant.

\section{MATERIALS AND METHODS}

Plant material. The plant materials used were the same as, or similar to, those used previously $(11,12)$. These were: virustested Ribes spp. and cultivars held at the Scottish Crop Research Institute and used as healthy controls, similar material graft inoculated previously with blackcurrant 
scions infected with one or other of the two forms of reversion disease ( $E$ and $\mathrm{R}$ ), and blackcurrant cultivars infected naturally with the $\mathrm{E}$ form of the disease in the field. All the infected Ribes plants tested had been affected with reversion disease for more than 5 years, so that disease symptoms in blackcurrant were evident in all branches. Red currant plants graft inoculated with BRV showed few or no symptoms.

Mechanical inoculation of blackcurrant plants with partially purified virus preparations. In February 1996, BRV particles were purified and concentrated from infected Chenopodium quinoa leaves using the method described previously (12) and inoculated mechanically to four plants each of the blackcurrant cvs. Ben Sarek and Ben Tron dusted previously with the abrasive, Corundum. These plants were derived from virus-tested stock plants and were grown in an insect-proof glasshouse before and after virus inoculation. Plants were shaded with newspaper for $24 \mathrm{~h}$ prior to inoculation and for $12 \mathrm{~h}$ after inoculation. In each year, all plants were treated with the systemic insecticide, Temek, in the early spring to minimize the risk of colonization by mites, and were observed for virus symptoms and assayed for BRV by RT-PCR using either the method of Lemmetty et al. (12) or, latterly, that given in this article.

Virus-specific PCR primers. Based on the published sequence for the coat protein gene (10), primers were designed using the GCG program PRIME (4). Two new sets of oligonucleotide primers were designed and each produced an amplicon size of about $300 \mathrm{bp}$. The primer sequences were BR1 (forward) 5' ACG TTA GCT TGC AGT CCC AC 3', corresponding to nucleotide positions 653 to 672 upstream from the poly(A) tail; BR3 (reverse) 5' CCA GGA AAG ACG AGT GCT T 3', complimentary to nucleotide positions 966 to 984 ; BR2 (forward) 5' TGG TGA GGT GGT GCA TAC TGG 3', corresponding to nucleotide positions 877 to 897; and BR4 (reverse) 5' CCA ATC GTT CGA GGT GGG GCT CC 3', complementary to nucleotide positions 1,166 to 1,188 .

For nested PCR, the first round of RTPCR amplification used primers BR1 (F) and BR4 (R) to give a product of $537 \mathrm{bp}$,

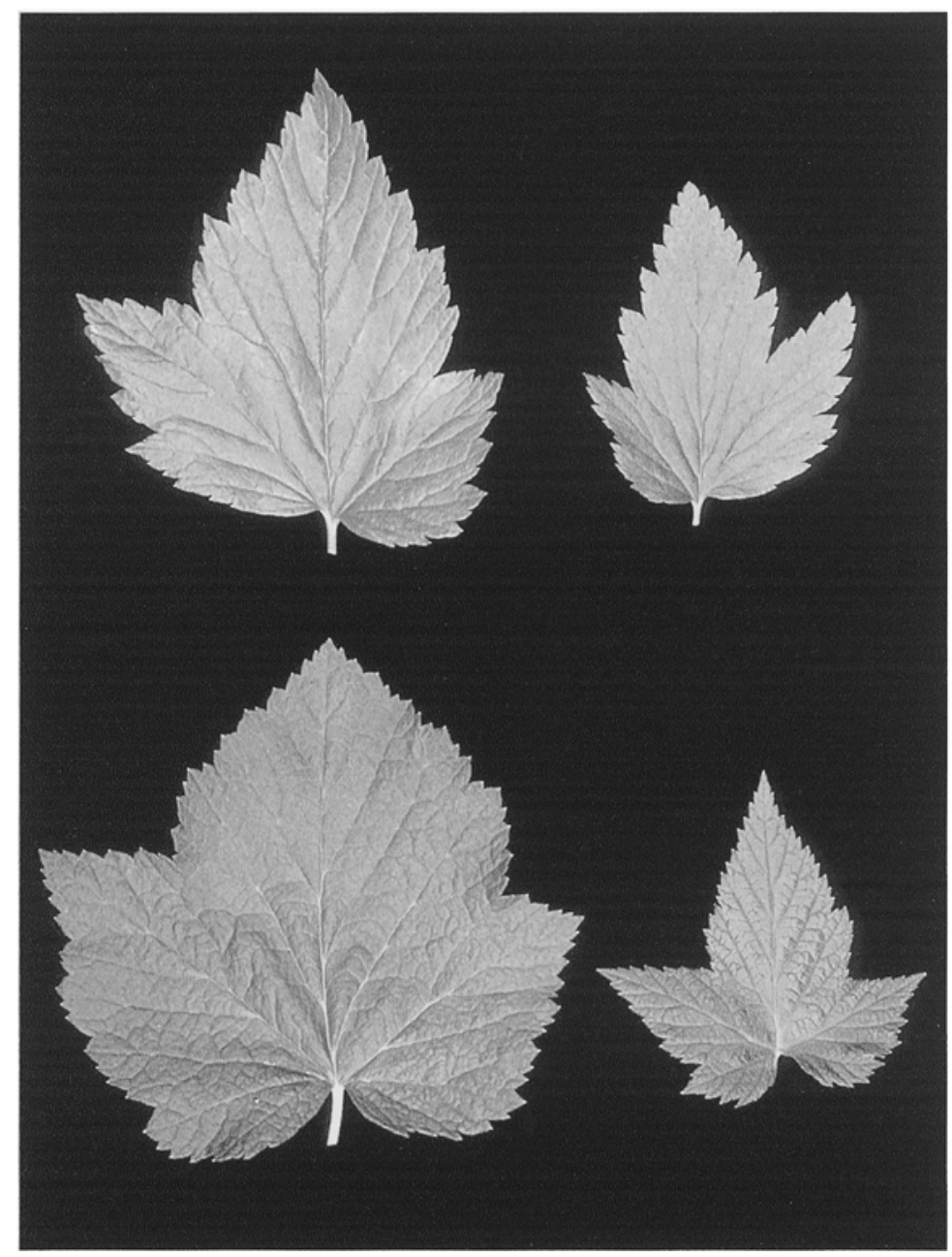

Fig. 1. Young and old leaves of 'Ben Sarek' blackcurrant from a plant that is healthy (bottom) and one that was inoculated mechanically with a partially purified preparation of Blackcurrant reversion virus (BRV) 2 years previously (top). Leaves from the BRV-inoculated plant show classical leaf symptoms of reversion disease. and the second round used primers BR2 (F) and BR3 (R) to produce an amplicon of 108 bp.

Extraction of BRV RNA from plants. Unless stated otherwise, in all experiments, five or six randomly collected buds near the tips of plants were used.

New method $(N)$. Buds were ground in 2 $\mathrm{ml}$ of phosphate-buffered saline containing $0.05 \%$ Tween-20 (vol/vol), $2 \%$ (wt/vol) polyvinylpyrollidone (PVP), and $0.2 \%$ (wt/vol) ovalbumin (PBS-TPO) in a pestle and mortar. The extract was centrifuged for $2 \mathrm{~min}$ at $3,000 \times g$ and, to trap virus particles, $200 \mu \mathrm{l}$ of the supernatant fluid was transferred to a well of an enzyme-linked immunosorbent assay (ELISA) microtiter plate either coated with antibodies to BRV or left uncoated, and kept at $4^{\circ} \mathrm{C}$ overnight (or for $16 \mathrm{~h}$ ). The ELISA plate then was emptied and washed once in PBS-TPO and then again in water. The plate was placed on ice and $10 \mu \mathrm{l}$ of $3 \%$ Triton-X100 was added to the well and mixed by repeated siphoning and expelling the mixture with a pipette to disrupt virus particles before use for RT-PCR.

Previously used method (P). For comparative studies, essentially the original extraction protocol (12) was used. Briefly, buds were powdered in liquid nitrogen, extracted in $0.01 \mathrm{M}$ Tris- $\mathrm{HCl}$ buffer, $\mathrm{pH}$ 7.5, containing $0.001 \mathrm{M}$ EDTA (TE), placed at $-20^{\circ} \mathrm{C}$ for $20 \mathrm{~min}$, and thawed by restoring to room temperature for several minutes before centrifuging for $5 \mathrm{~min}$ at $2,000 \times g$. The supernatant fluid $(100 \mu \mathrm{l})$ then was placed in an ELISA plate either coated with antibodies to BRV or left uncoated, and kept at $4^{\circ} \mathrm{C}$ overnight (or for $16 \mathrm{~h}$ ). The ELISA plate was emptied and washed three times in PBS-Tween-20 before $8 \mu$ of sterile water was added and the plate incubated at $65^{\circ} \mathrm{C}$ for $10 \mathrm{~min}$ to disrupt virus particles. This extract then was used for RT-PCR. In some experiments using protocol $\mathrm{P}$, a temperature of $90^{\circ} \mathrm{C}$ was used to disrupt trapped virus particles instead of $65^{\circ} \mathrm{C}$ as reported by Lemmetty et al. (15).

RT-PCR. Protocol $N$. For RT-PCR, PCR tubes containing an RT-PCR bead (Ready-to-go PCR Beads, Amersham Pharmacia Biotech) were placed on ice and $38 \mu \mathrm{l}$ of sterile water added. After $5 \mathrm{~min}, 1$ $\mu \mathrm{l}$ of each primer ( $10 \mathrm{pmol} / \mu \mathrm{l}$ each $)$ and 10 $\mu \mathrm{l}$ of template RNA from the ELISA plate was added to the tube prior to hot-start RTPCR. The PCR temperature conditions were optimized in a Hybaid PCR Express machine fitted with a temperature gradient block. For the primer set BR1/BR3, the PCR conditions were $42^{\circ} \mathrm{C}$ for $60 \mathrm{~min}$, $94^{\circ} \mathrm{C}$ for $5 \mathrm{~min}$, and then $30-33$ cycles of $94^{\circ} \mathrm{C}$ for $1 \mathrm{~min}, 62^{\circ} \mathrm{C}$ for $1 \mathrm{~min}, 72^{\circ} \mathrm{C}$ for 1 min, and then $72^{\circ} \mathrm{C}$ for $10 \mathrm{~min}$. For primer set BR2/BR4, the PCR conditions were: $42^{\circ} \mathrm{C}$ for $30 \mathrm{~min}, 94^{\circ} \mathrm{C}$ for $5 \mathrm{~min}$, and then 30 to 35 cycles of $94^{\circ} \mathrm{C}$ for $1 \mathrm{~min}, 62^{\circ} \mathrm{C}$ for $1 \mathrm{~min}, 72^{\circ} \mathrm{C}$ for $1 \mathrm{~min}$, and $72^{\circ} \mathrm{C}$ for 10 
min. When using the primers of Lemmetty et al. (12) for comparative purposes, the annealing temperature was $37^{\circ} \mathrm{C}$ instead of $57^{\circ} \mathrm{C}$.

Protocol $P$. This was done essentially as described by Lemmetty et al. (12) using the 12- and 15-mer primers and in which cDNA synthesis and PCR were done separately. In comparative studies using the new primer sets, BR1/BR3 and BR2/BR4, $1 \mu \mathrm{l}$ instead of $2 \mu \mathrm{l}$ of primer and $80.5 \mu \mathrm{l}$ instead of $78.5 \mu$ l of water were used. The PCR conditions were $94^{\circ} \mathrm{C}$ for $5 \mathrm{~min}$ and 30 to 35 cycles of $94^{\circ} \mathrm{C}$ for $1 \mathrm{~min}, 37^{\circ} \mathrm{C}$ for $1 \mathrm{~min}, 72^{\circ} \mathrm{C}$ for $1 \mathrm{~min}$, and then $72^{\circ} \mathrm{C}$ for $10 \mathrm{~min}$. When our new primer sets were used, the annealing temperature was $57^{\circ} \mathrm{C}$ instead of $37^{\circ} \mathrm{C}$.

A comparison of the major features of the two different RT-PCR protocols is summarized in Table 1.

Nested PCR. For nested PCR, the first round RT-PCR conditions were $42^{\circ} \mathrm{C}$ for $60 \mathrm{~min}, 94^{\circ} \mathrm{C}$ for $5 \mathrm{~min}$, and then 33 cycles of $94^{\circ} \mathrm{C}$ for $1 \mathrm{~min}, 62^{\circ} \mathrm{C}$ for $1 \mathrm{~min}, 72^{\circ} \mathrm{C}$ for $1 \mathrm{~min}$, and $72^{\circ} \mathrm{C}$ for $10 \mathrm{~min}$. For the second PCR round, $1 \mu$ of a 1:10 dilution of the mixture from the first round was added to a tube containing a Ready-to-go PCR bead, $1 \mu \mathrm{l}$ of each primer $(10 \mathrm{pmol} / \mu \mathrm{l}$ each), and $22 \mu$ of sterile water. The PCR conditions were $94^{\circ} \mathrm{C}$ for $5 \mathrm{~min} ; 33$ cycles of $94^{\circ} \mathrm{C}$ for $1 \mathrm{~min}, 56^{\circ} \mathrm{C}$ for $1 \mathrm{~min}$, and $72^{\circ} \mathrm{C}$ for $1 \mathrm{~min}$; and then $72^{\circ} \mathrm{C}$ for $10 \mathrm{~min}$.

Analysis of PCR products. The amplified products were analyzed by electrophoresis in a $4 \%$ polyacrylamide gel, stained with ethidium bromide, and photographed under UV light.

\section{RESULTS}

Development of reversion disease in blackcurrant plants mechanically inoculated with partially purified BRV preparations. BRV was not detected in any of the eight mechanically inoculated blackcurrant plants using protocol $\mathrm{P}$ until 3 years after their inoculation, when all but one (cv. Ben Tron) of these plants were positive for BRV. However, the PCR product detected was often very weak. Nevertheless, 2 years after inoculation, a branch of one cv. Ben Sarek plant showed classi- cal reversion of the leaves (Fig. 1) and, 3 years after inoculation, a few branches of one infected plant of cv. Ben Tron showed greatly increased pigmentation of flowers; however, the sepals were normal and not divided, unlike most plants affected with the $\mathrm{R}$ form of reversion. In the fourth and fifth year after inoculation, leaves on branches of two infected plants of each cultivar showed typical reversion symptoms (Fig. 1) and several flower buds on these were hairless on emergence. However, throughout the course of this study, no deformed flowers typical of the $\mathrm{R}$ form of BRV were observed.

General observations on the RT-PCR protocols. RT-PCR protocols $\mathrm{N}$ and $\mathrm{P}$ were compared and stepwise modifications of them were used to identify the most important parameters to achieve maximum sensitivity in detecting BRV. In initial studies, there appeared to be little difference in the sensitivity of detecting BRV in young leaves and dormant buds of blackcurrant, but detection in red currant was always very difficult from both plant sources. Therefore, unless stated otherwise, all experiments used dormant buds.

Protocol P was generally less than $50 \%$ reliable in detecting BRV in leaves of known reverted blackcurrant plants during the early growing season and in buds during the dormant season. Furthermore, even when detectable, the amount of PCR product from these sources was sometimes very small, and some samples often required a second assay to confirm infection. The sources giving these weak PCR products varied from assay to assay, and sometimes even from the same plant.

When used under optimized conditions for protocol N PCR, primer sets BR1/ BR3 were very similar in the results they produced from the same Ribes extracts. Unless stated otherwise, all the studies reported below refer to primer pair BR1.

Trapping of BRV particles prior to the RT step. When IC and direct plate trapping (PT) of BRV particles was compared using the same source plant extract and retaining all the other features of the respective RT-PCR protocols, there was usually little difference in the sensitivity of
BRV detection (data not shown). In some assays, IC seemed to decrease the sensitivity of detection with each of the RT-PCR protocols, but this effect was not consistent. In all further assays, PT was used to trap BRV particles prior to the extraction of RNA for each RT-PCR protocol.

Method of extracting RNA from plate-trapped BRV particles. Using the same blackcurrant source material, comparisons were made of TritonX-100 (proto$\operatorname{col~N}$ ) and heat denaturation at $65^{\circ} \mathrm{C}$ (protocol $\mathrm{P}$ ) and $90^{\circ} \mathrm{C}$ (modified protocol $\mathrm{P}$; 15) to disrupt PT virus particles on ELISA plates to release viral RNA for RT. In this test, using the optimized conditions in each of the two RT-PCR protocols, only TritonX-100 (protocol N) produced a PCR product from BRV-infected blackcurrant (Fig. 2).

Efficacy of the different primer pairs. When the optimized RT-PCR conditions for the two different primer sets were each used in protocols $\mathrm{N}$ and $\mathrm{P}$, only protocol $\mathrm{N}$ using the primer pair BR1/BR3 was effective in unambiguously detecting BRV in blackcurrant and in some infected red currant. Sometimes a very faint PCR product was produced from infected blackcurrant using protocol $\mathrm{P}$ and the old primer set (12), but none of the other combinations produced a PCR product of the correct size (Fig. 3). When protocol $\mathrm{N}$ was used with either sets of primers under the optimized PCR conditions for each primer set, only primer pair BR1/BR3 detected BRV but, in several assays, it failed to detected BRV in infected red currant (Fig. 4A).

Other changes. In attempts to improve further the sensitivity of detecting BRV, the optimum RT time was determined to be 60 min and the number of PCR cycles increased from 30 to 33 . Nevertheless, even with these combined changes that maximized the detection of BRV in blackcurrant, the detection of BRV in red currant was always unreliable.

Nested PCR detection of BRV. Because of the difficulty in detecting BRV reliably in red currant by RT-PCR, nested PCR was developed and compared with the optimized RT-PCR protocol $\mathrm{N}$ in a range of $\mathrm{BRV}$-infected red currant culti-

Table 1. Comparative summary of the main features of the two reverse transcriptase-polymerase chain reaction (RT-PCR) protocols used to detect Blackcurrant reversion virus (BRV) in Ribes spp. ${ }^{\mathrm{a}}$

\begin{tabular}{lll}
\hline Step & Previous protocol $(\mathbf{P})(\mathbf{1 2}, \mathbf{1 5})$ & New protocol (N) \\
\hline BRV extraction & $\mathrm{N}_{2}$ in TE buffer, freeze/thaw & Ground in PBS-TPO buffer \\
BRV trapping & Immunocapture & Plate trapping \\
Particle disruption & 65 or $90^{\circ} \mathrm{C}$ for $10 \mathrm{~min}$ & $3 \%$ Triton-X100 \\
Primers to coat protein sequence & 12 to 15 mer & 18 to 23 mer \\
RT reaction & cDNA synthesis kit & Ready-to-go RT-PCR beads \\
PCR reaction & Hot start & Ready-to-go RT-PCR beads \\
Annealing temperature & $37^{\circ} \mathrm{C}$ for 1 min & 57 to $62^{\circ} \mathrm{C}$ for 1 min \\
Number of cycles & 30 & 33 \\
Amplicon size & $210 \mathrm{bp}$ & 313 bp \\
\hline
\end{tabular}

a TE buffer $=0.01 \mathrm{M}$ Tris-HCl buffer, $\mathrm{pH} 7.5$, containing $0.001 \mathrm{M}$ EDTA; PBS-TPO buffer $=$ phosphate-buffered saline containing $0.05 \%$ Tween-20 ( $\mathrm{vol} / \mathrm{vol}), 2 \%(\mathrm{wt} / \mathrm{vol})$ polyvinylpyrollidone (PVP), and $0.2 \%(\mathrm{wt} / \mathrm{vol})$ ovalbumin.

${ }^{\mathrm{b}} \mathrm{RT}-\mathrm{PCR}$ done in a single tube. 
vars. The much greater sensitivity of nested PCR in detecting BRV in this material is clearly shown in Figure 4, as is the great variation between plants in the amount of the BRV PCR product produced.

\section{DISCUSSION}

The findings reported here, and supported by very recent work from others (13), demonstrate that BRV is the causal

agent of blackcurrant reversion disease. The 4 to 5 years required from experimental inoculation of blackcurrant plants with BRV particle preparations to the development in plants of the full reversion disease symptoms emphasizes the very slow and erratic systemic movement of the virus in blackcurrant. Reversion symptoms develop much more rapidly in plants in the field and in graft-inoculated plants $(7,8)$ but this may be due to the greater inoculum load

\section{B} $\begin{array}{lllll}1 & 2 & 3 & 4 & 5\end{array}$ 123

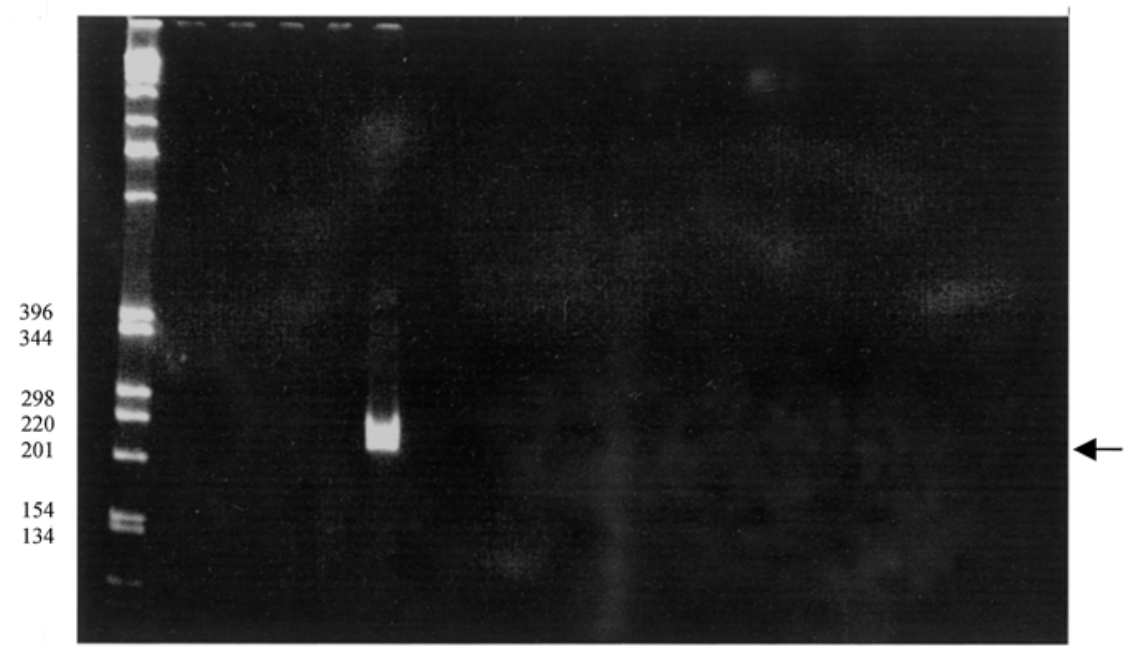

Fig. 2. Polyacrylamide gel electrophoresis to detect a Blackcurrant reversion virus (BRV)-specific reverse transcriptase-polymerase chain reaction product (arrow) using $\mathbf{A}$, protocol N, and $\mathbf{B}$ and $\mathbf{C}$, protocol P, showing the effect on the amount of product detected following different methods to extract viral RNA from BRV particles trapped on uncoated microtiter plates. A, TritonX-100, B, heating to $65^{\circ} \mathrm{C}, \mathrm{C}$, heating to $90^{\circ} \mathrm{C}$. Lanes contain products from water control (1), healthy 'Fays Prolific' red currant (2), healthy 'Ben Tron' blackcurrant (3), and BRV-infected 'Jonkeers van Tets' red currant (4) and 'Ben Lomond' blackcurrant (5). Lane M contains a DNA size marker.

A

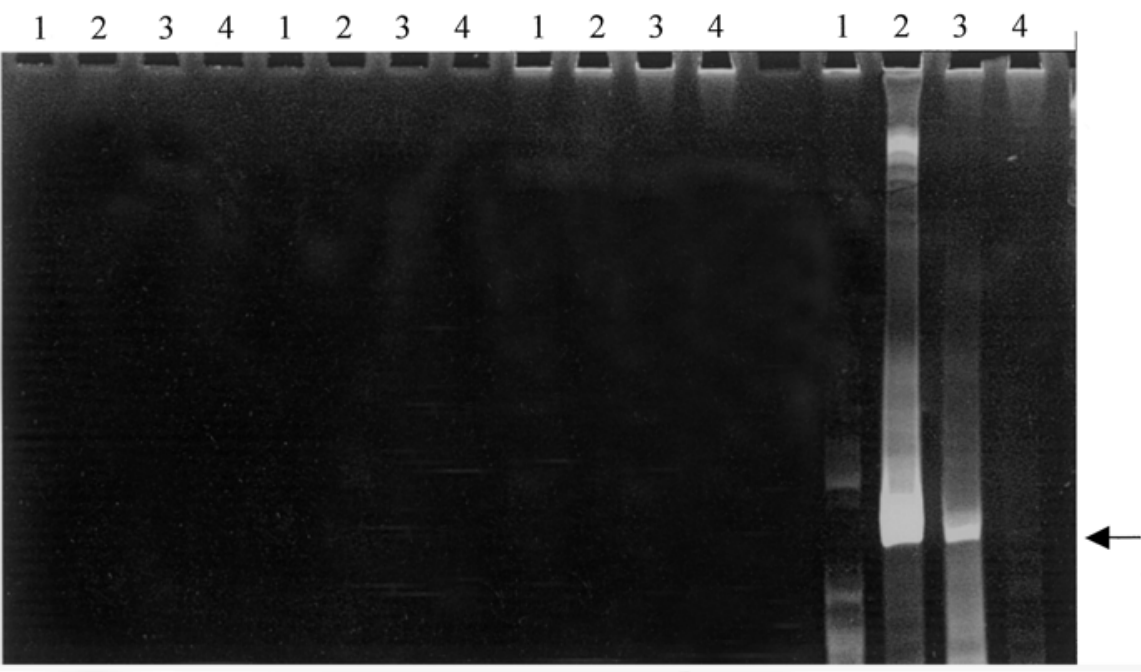

Fig. 3. Polyacrylamide gel electrophoresis to detect a Blackcurrant reversion virus (BRV)-specific reverse transcriptase-polymerase chain reaction (RT-PCR) product (arrow) using RT-PCR protocols P and N, 33 cycles of amplification, and two different primer sets. The different treatments are $\mathbf{A}$, protocol $\mathrm{P}$ and new primers, $\mathbf{B}$, protocol $\mathrm{P}$ and previous primers, $\mathbf{C}$, protocol $\mathrm{N}$ and previous primers, and $\mathbf{D}$, protocol $\mathrm{N}$ and new primers. Each block of four lanes contains the products from extracts of healthy 'Ben Sarek' blackcurrant (1), BRV-infected 'Ben Lomond' blackcurrant (2), BRV-infected 'Jonkeers van Tets' red currant (3), and water control (4). over a longer period of time than under the experimental conditions used here. During the 5 years of observing the BRV-inoculated plants, we have not seen the severe flower symptom characteristic of the $\mathrm{R}$ form of the disease in any of these plants. This may be due to the cultivars used (although all tested cultivars show this symptom following graft inoculation), the warmer growing conditions in the glasshouse, and/or the need for a longer incubation period after infection. In similar experiments in Finland, such symptoms have now developed on a few flowers of one infected blackcurrant plant, but only 4 years after inoculation with BRV preparations $(13,14)$, confirming that BRV is the causal agent of this symptom also.

Currently, detection of blackcurrant reversion disease in Ribes plants is determined by graft-inoculating material to sensitive blackcurrant cultivars. This is a widely used and reliable assay but results from such biological tests usually are not available for at least 2 years $(1,5,7)$. Clearly, a more rapid assay for screening material for infection offers the potential of great savings in time, glasshouse space, efficiency, and cost. Such an assay also would provide an essential tool to study more accurately and rapidly the epidemiology and ecology of the disease in crops, to identify resistant germplasm, to determine the mode of inheritance of such resistance, and to enable the rapid release of virustested material to commerce.

The molecular characterization of BRV and the development of an RT-PCR assay to detect it rapidly in Ribes spp. $(11,12)$ have gone a long way toward providing a rapid assay for infection. However, the ICRT-PCR protocol for detecting BRV reported previously (12) is not completely reliable; therefore, it has not been used widely by quarantine and certification programs in the UK and overseas (A. T. Jones, unpublished data). Our difficulty, noted in this article, in reliably detecting BRV in BRV-infected Ribes samples using this protocol confirms earlier $(11,12)$ and more recent (15) studies. Although the demonstrated erratic distribution or concentration of BRV in different nodes of infected plants (11) may largely explain the reason or reasons for this unreliability, it also reveals the limitations of the assay to detect such low virus concentrations. BRV detection in red currant was always very unreliable using this protocol and, in most instances, failed to detect infection in known BRV-infected plants.

In direct comparisons with the previously used RT-PCR protocols $(11,12)$, the protocol developed here produced enhanced reliability (>90\%) of BRV detection in assays on blackcurrant. Nevertheless, detection of BRV in red currant was less than $36 \%$, although there was some evidence that detection increased during early spring (data not shown). Several 
different modifications to the parameters of the original protocol (Table 1) contributed to the improved reliability, but three main factors operating together seem to be the most significant. First, the extraction of RNA from trapped BRV particles using TritonX-100 (Fig. 2); second, the development of new primers and their higher an-
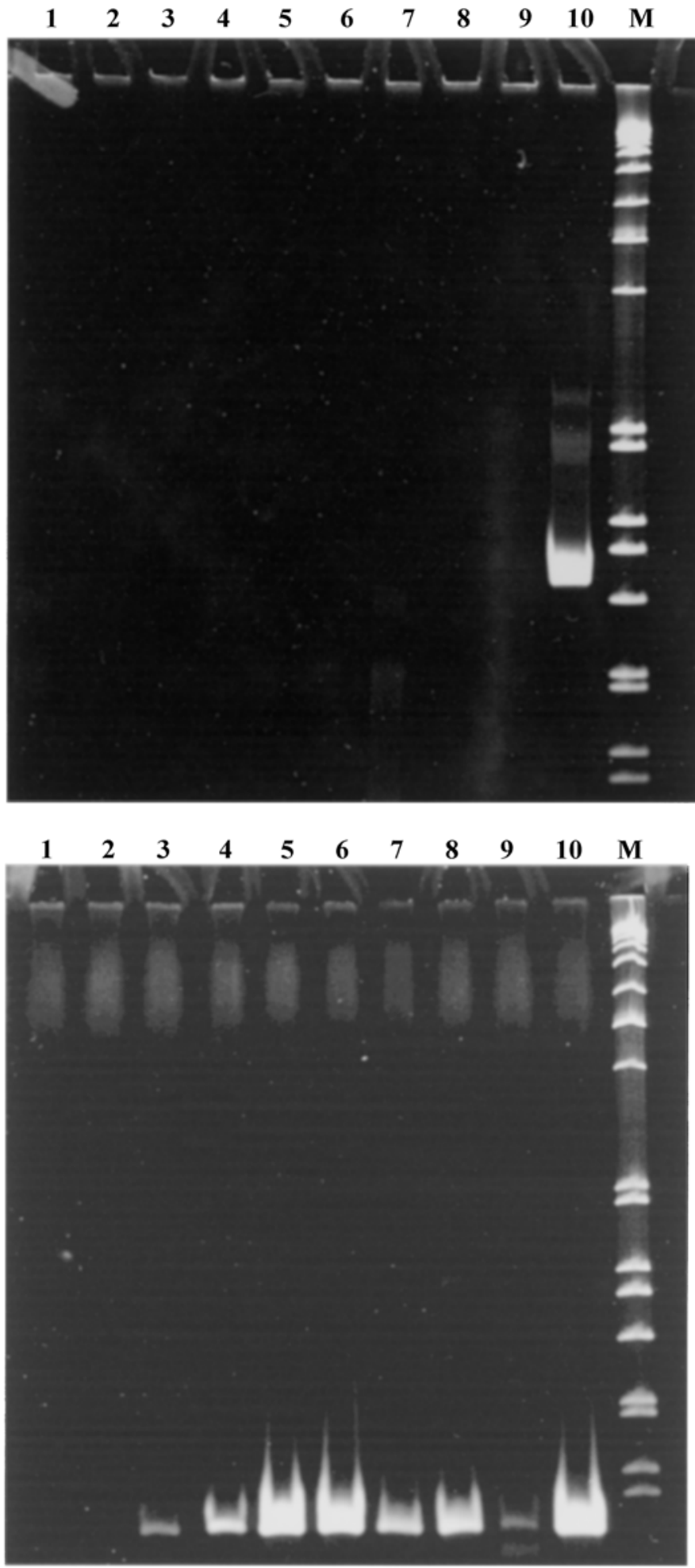

Fig. 4. Polyacrylamide gel electrophoresis comparing reverse transcriptase-polymerase chain reaction (RT-PCR) a, protocol $\mathrm{N}$ and $\mathbf{b}$, nested PCR to detect a Blackcurrant reversion virus (BRV)specific PCR product in BRV-infected red currant. In each photograph, lanes were loaded with PCR products from extracts of water (1); healthy blackcurrant (2); reversion-infected red currant 'Fays Prolific' (3), 'Jonkeers van Tets' (4-6), and 'Red Lake' (7-9); and reverted 'Ben Nevis' blackcurrant (10). Material in lanes 4, 7, and 8 was from plants infected with the severe (R) form of BRV and lanes 3, 5, 6, and 9 from plants infected with the European (E) form of BRV. Lane M contains a DNA size marker given in base pairs.

nealing temperatures; and third, the use of Ready-to-go RT-PCR beads. When one or more of these items occurred without the other, either poor or no amplification often resulted (Figs. 2 and 3).

The improvement in detection we found using TritonX-100 to disrupt trapped virus particles contrasts markedly with an earlier study (11) and is difficult to explain. Possibly, the different preparation of plant material in the new protocol may have influenced this. Also, in contrast to earlier published studies (11), we found that IC of virus particles on ELISA plates was not necessary and that equivalent or better results were obtained using PT (data not shown). This may be due to the higher binding capacity of ELISA plates compared with PCR tubes used in some tests previously (11). Further improvements in sensitivity were obtained by changes in the method of extracting BRV from Ribes tissue, and by increasing the RT time to 60 min and the PCR cycle number to 33 (Table 1).

Despite these improvements in the RTPCR methodology, red currant still remained the most difficult Ribes material in which to detect BRV reliably, due presumably to the low and/or erratic distribution of the virus in these plants. The nested PCR for BRV developed here has now overcome this difficulty (Fig. 4A and B), but the great variation in the amount of the PCR amplicon detected in different red currant plants and in different assays emphasizes the continued requirement to pool samples of buds and leaves from different parts of plants for both assay systems. Although nested PCR also increased further the sensitivity of detecting BRV in blackcurrant, for most purposes, the revised RTPCR protocol gives a high level of reliability.

\section{ACKNOWLEDGMENTS}

We thank our colleagues B. Fenton for assistance in primer design and $\mathrm{G}$. Malloch for suggesting the use of the Ready-to-go RT-PCR beads, and K. Lehto, Turku, Finland for a gift of antiserum to BRV.

\section{LITERATURE CITED}

1. Adams, A. N., and Thresh, J. M. 1987. Reversion of black currant. Pages 133-136 in: Virus Diseases of Small Fruits. R. H. Converse, ed. U. S. Dep. Agric. Agric. Handb. No. 631.

2. Bremer, K. 1983. Viral diseases occurring on Ribes species in Finland. Ann. Agric. Fenn. 22:104-109.

3. Bremer, K., and Heikinheimo, O. 1980. Problems of the reversion disease of Ribes in Finland. Acta Hortic. 95:87-91.

4. Devereaux, J., Haeberli, P., and Smithies, O. 1984. A comprehensive set of sequence analysis programs for the VAX. Nucleic Acids Res. $12: 387-395$.

5. Jones, A. T. 1992. Appendix I. Recommended indexing procedures for detecting viruses, viroids, mycoplasma- and rickettsia-like organisms and virus-like diseases in small fruit crops: Currants and Gooseberries (Ribes). Acta Hortic. 308:151-154.

6. Jones, A. T. 1995. Black currant reversion and its eriophyid mite vector. Pages 33-37 in: Proc. Int. Symp.: Rose Rosette Other Mite- 
transmitted Dis. Agents Uncertain Etiol. Iowa State University, Ames.

7. Jones, A. T. 2000. Black currant reversion disease-the probable causal agent, eriophyid mite vectors, epidemiology and prospects for control. Virus Res. 71:71-84.

8. Jones, A. T, Brennan, R. M., McGavin, W. J., and Lemmetty, A. 1998. Galling and reversion disease incidence in a range of blackcurrant genotypes, differing in resistance to the blackcurrant gall mite (Cecidophyopsis ribis) and blackcurrant reversion disease. Ann. Appl. Biol. 133:375-384

9. Jones, A. T, and McGavin, W. J. 1996. A damaging outbreak of Arabis mosaic nepovirus in blackcurrant, the occurrence of other nepoviruses in Ribes species, and the demonstration that Alfalfa mosaic virus is the cause of in- terveinal white mosaic in blackcurrant. Ann. Appl. Biol. 129:47-55.

10. Latvala, S., Susi, P., Kalkkinen, N., and Lehto, K. 1997. Characterization of the coat protein gene of mite transmitted blackcurrant reversion associated nepovirus (BRAV). Virus Res. 53:1-11.

11. Latvala, S., Susi, P., Lemmetty, A., Cox, S., Jones, A. T., and Lehto, K. 1997. Ribes host range and distribution within plants of blackcurrant reversion associated virus provides further evidence for its probable role as the causal agent of reversion disease. Ann. Appl. Biol. 131:283-295.

12. Lemmetty, A., Latvala, S., Jones, A. T., Susi, P., McGavin, W. J., and Lehto, K. 1997. Purification and properties of a new virus from blackcurrant, its affinities with nepoviruses and its close association with blackcurrant reversion disease. Phytopathology 87:404-413.

13. Lemmetty, A., Latvala-Kilby, S., and Lehto, K. 2001. Comparison of different isolates of Blackcurrant reversion virus. Acta Hortic. 551:45-49.

14. Lemmetty, A., and Lehto, K. 1999. Successful back-inoculation confirms the role of blackcurrant reversion associated virus as the causal agent of reversion disease. Eur. J. Plant Pathol. 105:297-301.

15. Lemmetty, A., Susi, P., Latvala, S., and Lehto, K. 1998. Detection of the putative causal agent of blackcurrant reversion disease. Acta Hortic. 471:93-98.

16. Thomsen, A., Nielsen, S. L., and Rasmussen, A. N. 1991. Ribbesvind ogsolbaerknopgalmider. Havebrug Grøn Viden 65:1-4 (in Danish). 